\title{
A Study on Conservation of Church Buildings in Turkey: The Example of Yalova/Esenköy Azize Paraskevi Church
}

\author{
Tuba Nur Olğun* \\ * Frrat University, Faculty of Architecture, Departmant of Architecture, Elazığ, Turkey, (ORCID: 0000-0001-5654-0020), tnbaz@firat.edu.tr
}

(1st International Conference on Applied Engineering and Natural Sciences ICAENS 2021, November 1-3, 2021)

(DOI: $10.31590 /$ ejosat.1012945)

ATIF/REFERENCE: Olğun, T. N. (2021). A Study on Conservation of Church Buildings in Turkey: The Example of Yalova/Esenköy Azize Paraskevi Church. European Journal of Science and Technology, (28), 1107-1111.

\begin{abstract}
Turkey, with its strategic location and deep-rooted past, has been a settlement area that has attracted the attention of many civilizations in the process that has reached the present day. In many parts of Anatolia, great civilizations ruled and artifacts reflecting the cultural characteristics of the period remained. At the forefront of these works are the places of worship that date back to almost as old as the history of humanity.

Worship has been considered as a vital need for humanity since ancient times. In this context, the act of worshiping continued for many years, both in the open area and inside the structures designed and built specifically for the faith. Although each belief brings its own requirements in terms of places of worship, it is possible to state that there are many common points, especially in terms of architecture. In this sense, the documentation and examination of the worship structures that have survived from the past and stand out with their qualities worth conserving are also of great importance in terms of providing inspiration for the designs of the places of worship that will be built in the future.

The aim of the study is to examine the conservation status of church buildings, which are widely seen all over the world and have important examples in Turkey, and in this context; To contribute to the conservation of Esenköy Azize Paraskevi Church, about which there is not enough information in the literature. Within the scope of the study, various church structures in Turkey that are under conservation were examined in the light of the relevant literature. Then, the present situation of the Esenköy Azize Paraskevi church was discussed and evaluations were made on the state of conservation. The study method consists of examining the sources and onsite observations. As a result, it is thought that the study will draw attention to the problems of church buildings in Turkey in the context of the conservation of all worship buildings and the importance of Esenköy Azize Paraskevi Church in terms of conservation.
\end{abstract}

Keywords: Conservation, Church, Yalova, Esenköy, Azize Paraskevi Church.

\section{Türkiye'de Kilise Yapılarının Korunması Üzerine Bir Araştırma: Yalova/Esenköy Azize Paraskevi Kilisesi Örneği}

$\ddot{O} \mathbf{z}$

Türkiye, stratejik konumu ve köklü geçmişiyle, tarihten günümüze ulaşan süreçte pek çok medeniyetin ilgisini çeken bir yerleşim alanı olmuştur. Anadolu'nun birçok noktasında büyük medeniyetler hüküm sürmüş ve bunlardan geriye, dönemin kültürel niteliklerini yansıtan eserler kalmıştır. Bu eserlerin başında, geçmişi neredeyse insanlık tarihi kadar eskiye uzanan ibadet yapıları gelmektedir. İbadet, oldukça eski tarihlerden itibaren insanlık için yaşamsal bir ihtiyaç olarak değerlendirilmiştir. Bu bağlamda gerek açık alanda, gerekse inanca özgü olarak tasarlanan ve inşa edilen yapıların içinde uzun yıllar boyunca ibadet etme eylemi gerçekleştirilmeye devam etmiştir. Her inanç, ibadet mekânları açısından kendi gerekliliklerini beraberinde getirse de özellikle mimari anlamda pek çok ortak noktanın bulunduğunu belirtmek mümkündür. Bu anlamda geçmişten günümüze ulaşan ve korumaya değer nitelikleriyle öne çıkan ibadet yapılarının belgelenmesi ve incelenmesi, gelecekte inşa edilecek olan ibadet yapılarının tasarımlarına ilham kaynağı sağlamak açısından da büyük önem taşımaktadır.

Çalışmanın amacı, tüm dünyada yaygın olarak görülen ve Türkiye'de önemli örnekleri bulunan kilise yapılarının koruma durumunu irdelemek ve bu bağlamda; literatürde hakkında yeterince bilgi bulunmayan Esenköy Azize Paraskevi Kilisesi’nin korunmasına katkı sağlamaktır. Çalışma kapsamında Türkiye'de bulunan ve koruma altında olan çeşitli kilise yapıları, ilgili literatür ışığında incelenmiştir. Ardından Esenköy Azize Paraskevi kilisesinin günümüzdeki durumu ele alınarak korunmuşluk durumu üzerinden değerlendirmeler yapılmıştır. Çalışma yöntemini kaynakların incelenmesi ve yerinde gözlemler oluşturmaktadır. Sonuç olarak yapılan çalışma ile Türkiye'de, tüm ibadet yapılarının korunması bağlamında kilise yapılarının sorunlarına ve Esenköy Azize Paraskevi Kilisesi'nin koruma açısından önemine dikkatin çekileceği düşünülmektedir.

Anahtar Kelimeler: Koruma, Kilise, Yalova, Esenköy, Azize Paraskevi Kilisesi.

*Corresponding Author: tnbaz@firat.edu.tr 


\section{Introduction}

Places of worship have always been prominent structures as an important part of conservation work in architecture. The history of these places, which are mostly symbols, dates back to ancient times (Güngör Açıkgöz ve Ahunbay, 2008). Worship structures that have survived from the past are mostly synagogues, churches and mosques built for the worship of Judaism, Christianity and Islam.

Conservation approaches in architecture were developed primarily on the consideration of monumental structures (Ahunbay, 2004). In this context, buildings of worship have also been frequently discussed in terms of conservation. Many symbolic worship structures have been repaired in order to be conserved and passed on to future generations. However, many modest worship structures in Turkey were lost before they could be taken under conservation. In particular, the immigration of Jewish and Christian populations from the country in various periods caused the abandonment of synagogues and churches in the settlements of these groups. In this context, while some of the abandoned worship buildings are conserved; some of them have been destroyed or destroyed for various reasons.

The aim of the study is to make a reading through the Yalova/Esenköy Azize Paraskevi Church, which stands out with its modest qualities, regarding the conservation of churches from symbolic structures in Turkey and to make positive contributions in this sense. Within the scope of the study, first of all, the literature on the conservation status of historical church buildings in Turkey was examined. Then, the general characteristics of the Esenköy Azize Paraskevi Church were revealed and all the information obtained was evaluated together. The working method consists of on-site observations and source investigations.

\section{Conservation Status of Historical Church Buildings in Turkey}

Turkey, with its deep-rooted history and strategic location, has hosted many civilizations, cultures and beliefs. It is known that many areas with settlements since prehistoric times are within the borders of Turkey. In the following process, different states, nations and belief groups continued their existence in this geography. Among these groups, Christian communities were also found intensively.

Churches as places of worship of the Christian faith are widespread in many parts of the world. Turkey also has a rich stock in this sense, with church structures used by the Christian communities it hosted both in the past and today. Many studies have been carried out in order to conserve these structures and transfer them to future generations. However, it can be stated that the church buildings in some small settlements are in a dilapidated condition and have not been taken under conservation yet.

One of the prominent church structures in the context of conservation in Turkey is the Sent Antuan Church in Istanbul/Beyoğlu. The building, which was built in 1724 with the Gothic architectural style, was demolished due to the tramway line and it was started to be rebuilt in the same area in 1906. The structure, which continues to exist today with its Neo
Gothic style is used for tourism purposes as well as its original function (Atıc1 and İnceoğlu, 2020) (Figure 1).
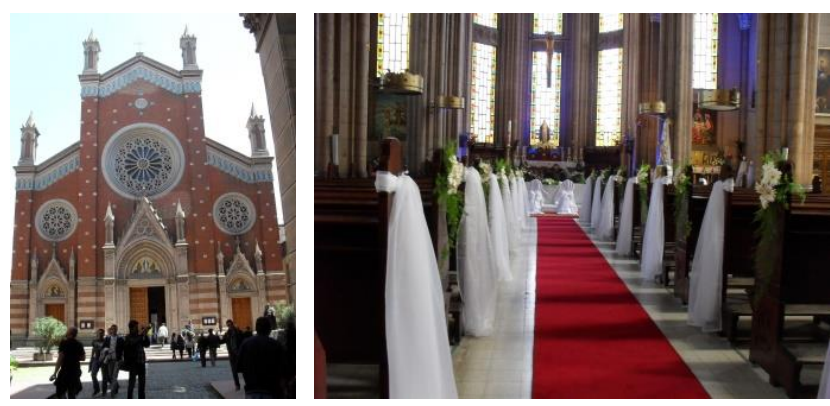

Figure 1. Saint Antuan Church under conservation, Istanbul (Personal archive, 2011)

One of the church structures that have survived and conserved in Turkey is located in Konya/Sille. The church structure, which is known to have been built in B.C. 327, has continued its existence with various repairs (Tapur, 2009). The building, which was one of the important worship centers of the period, serves as a museum today (Figure 2).
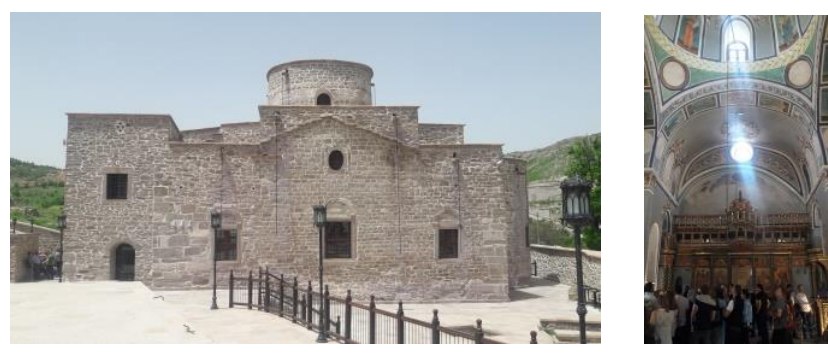

Figure 2. Aya Elenia Church under conservation, Konya (Personal archive, 2017)

Ayavukla Church, located in Izmir, is one of the places of worship that is of great importance in the context of conservation. The building, which was opened for worship in 1887, started to serve as the Izmir Archeology Museum in 1924, after its congregation left Turkey with the population exchange. The building, which has been evaluated with different functions in the processes that have reached the present day, started to host various cultural events with the completion of the restoration works in 2010 (URL 1) (Figure 3).
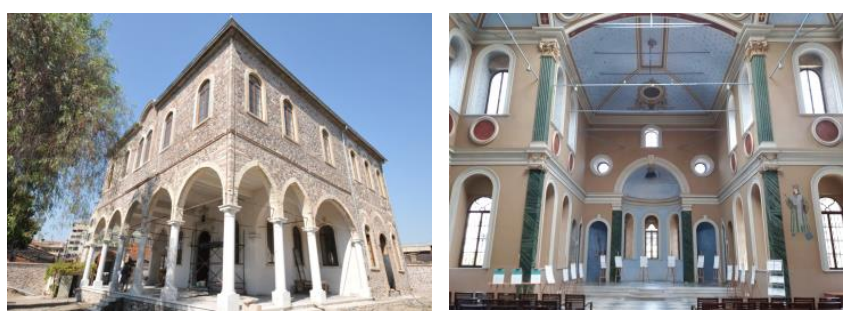

Figure 3. Ayavukla Church under conservation, Izmir (URL 2; Personal archive, 2018)

It is possible to talk about the existence of churches in a dilapidated condition in addition to the church structures that are under conservation in Turkey and continue their existence both with their original functions and with re-functioning. These structures can be found in various urban centers as well as in rural areas. In this sense, one of the examples identified is located in the İzmir/Urla countryside, in the Nohutalan District. The stone-material building was unused and neglected after the Christian population left the settlement due to the population exchange (Olğun and Yörür, 2020) (Figure 4). 

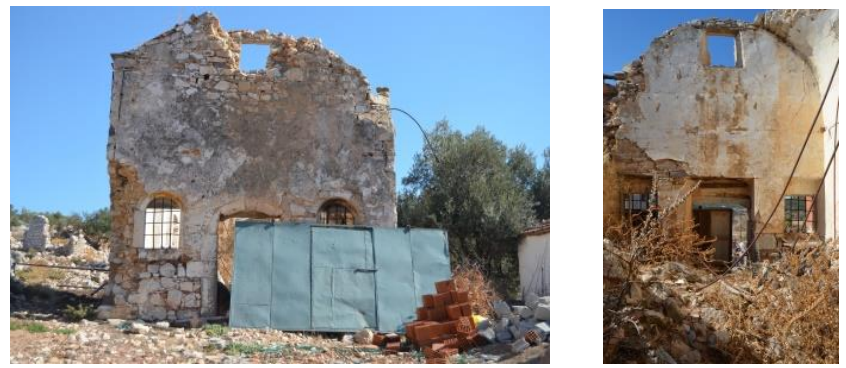
2020)

Figure 4. A ruined church building, Izmir (Olğun and Yörür,

Churches are monumental structures that contain many metaphors and symbolic features (Eşmeli, 2014). In this sense, not only as a worship structure; it is possible to consider them as symbols worth conserving in terms of the intangible values of the settlements in which they are located. In this context, Esenköy Azize Paraskevi Church is one of the church structures that has not yet been taken under conservation in Turkey, but stands out symbolically. It is important to reveal the characteristics of the building and to examine its conservation status, in the context of emphasizing the importance of other church structures in a similar situation.

\section{Investigation of Esenköy Azize Paraskevi Church}

Esenköy is a town in the Çnarcık district of Yalova province (Figure 5, Figure 6). Located on the shores of the Marmara Sea, the settlement has hosted users of Greek origin for many years in the past. Muslim families of Caucasian and Laz origin settled in place of the Greeks who had to leave the settlement with the population exchange. This situation has brought socio-cultural and economic changes in Esenköy (URL $3)$.

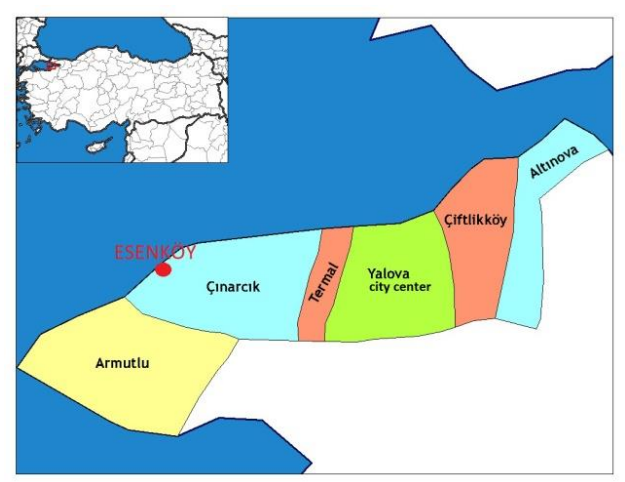
Fig
URL 4)

Figure 5. Location of Esenköy in Yalova (Prepared by using 
The construction date of Azize Paraskevi Church is unknown. It is approximately $23 \mathrm{~m}$ long, $13 \mathrm{~m}$ wide and $7.50 \mathrm{~m}$ high (Figure 9). Looking at the ruins in the interior, it is thought that the entrance to the building is on the western facade. However, three more entrance doors have been added to the building in the process that has reached the present day. In addition, many non-original windows were seen on the north, south and east facades. However, there is a residential structure that was built later, adjacent to the western facade of the building (Esenköy Municipality, 2021).

\section{2,94}

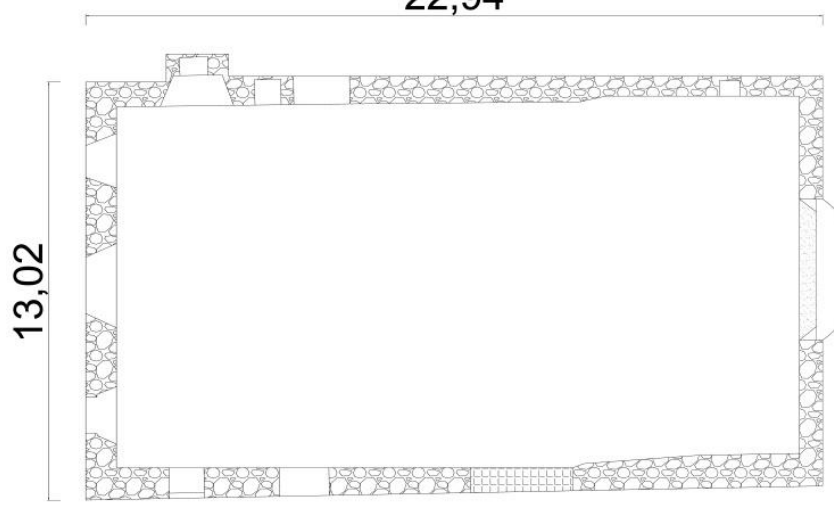

Figure 9. Azize Paraskevi Church +1.00 level schematic plan (Prepared by using Esenköy Municipality, 2021)

The material of the building mainly consists of rubble stones. However, it can be stated that the use of bricks is intense especially at the points where the door-window arches are located and under the roof eaves. It has been observed that some of the door-window spaces have wooden joinery, but there is no information about their authenticity.

The church structure is in a very dilapidated condition today. There are few elements of the building in its interior. These can be listed as niches, apses, windows and doors (Figure 10, Figure 11). No items that could be associated with this building were found in its surroundings. New residences continue to be built in the immediate vicinity of the building. However, many unqualified buildings adjacent to the site were removed.

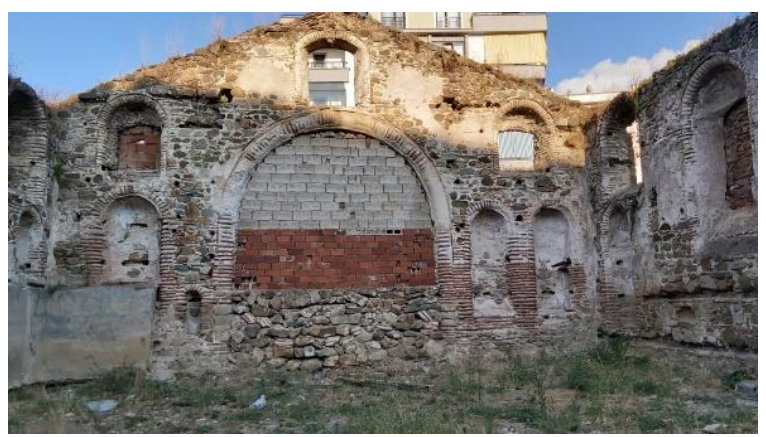

Figure 10. The apse and niches of Azize Paraskevi Church (Personal archive, 2021)

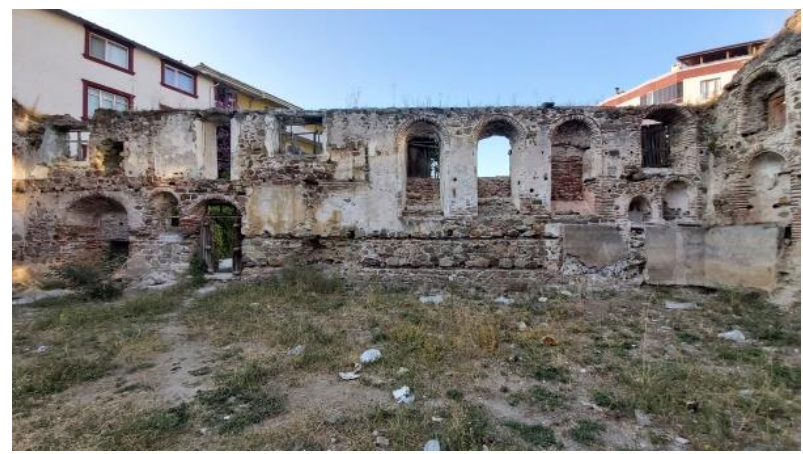

Figure 11. Apertures in the north wall of Azize Paraskevi Church (Personal archive, 2021)

The church structure is mostly made of stone material. However, there is also the use of bricks under the eaves of the roof, in the arches above the window and door openings, and at various points on the walls. The wall thicknesses of the building, which was built with a masonry system, vary between approximately $82-93 \mathrm{~cm}$.

Although Azize Paraskevi Church is located at a central point of Esenköy as a town connected to the touristic province of Yalova on the shore of the Marmara Sea, it is in a very dilapidated condition today. The outer walls of the building have partially survived. There are occasional abrasions and losses on these walls. However, the building was used as a house for a while; for this reason, it is known that apertures contrary to the original are created in the walls (Esenköy Municipality, 2021). The top cover of the church has completely disappeared. Interior items have also not survived to a large extent. The fact that all the users of the settlement are here after the population exchange makes it difficult to obtain information about the history of the building. In this sense, the problems of the Azize Paraskevi Church in terms of conservation can be listed as follows:

- The building remained idle due to the abandonment of its users.

- The fact that the new users of the settlement belong to a different belief has been effective in losing the importance of the building.

- The fact that the building is located at a central point in the settlement has accelerated the process of extinction under the influence of rapid and unplanned urbanization.

- The conservation and repair of the building was delayed due to the lack of conservation awareness and the effect of rent.

- The complete loss of the top cover has been effective in accelerating the structural damage.

- Under the influence of inappropriate functional changes, unqualified and unoriginal interventions were made.

The above-mentioned conservation problems can be considered as important obstacles to the correct transmission of the Saint Paraskevi Church to future generations. For the solution of these problems, both by local governments; as well as the steps to be taken on the initiative of the users of the settlement and the applications to be made by the experts can be considered as the most basic requirements for the conservation of the church. 


\section{Conclusion}

Historical worship buildings, as the reflections of a deeprooted culture and tradition, are artifacts that have an important place today and are considered worthy of conservation. In this context, church buildings are frequently discussed in the field of architectural conservation, as one of the prominent values of the Christian faith. Thus, there are many historical church structures that have survived to the present day.

When we look at the state of conservation of historical church buildings in Turkey, it can be stated that the structures located in important centers and in qualified areas that have hosted great civilizations are more conserved. However, it is possible to talk about the existence of ruined church structures in many settlements located in small-scale settlements and abandoned by their users for various reasons, although there are conserved church structures. One of them is Esenköy Azize Paraskevi Church.

Azize Paraskevi Church has a highly qualified structure in terms of materials and construction system. However, many factors such as irregular construction, rent, lack of conservation awareness, and vandalism have caused this structure to not be conserved. In this sense, the measures that can be effective in order to conserve the structure and transfer it to future generations can be listed as follows:

- Clearing the building from unqualified structuring around the church,

- Documentation work,

- Preparation of its restitution with detailed research on its past,

- Considering the absence of the congregation, its re-using with an appropriate function and the preparation of the restoration project accordingly,

- Giving information to the users of the settlement about the importance of the building and raising awareness of conservation.

In addition to the suggestions mentioned, the developments in the conservation process of similar structures that are under protection today can be investigated and evaluated in the context of Azize Paraskevi Church and practices can be developed accordingly. As a result, it is thought that with the study, the importance of historical church structures is emphasized and it contributes to the preservation of Esenköy Azize Paraskevi Church as a value that is about to disappear.

\section{References}

Ahunbay, Z. (2004). Historic Environment Conservation and Restoration, Istanbul, Turkey: YEM Publication.

Atıc1, E. and İnceoğlu, M. (2020). "The Legibility of Saint Anthony Church from an Architectural Perspective", Journal of the Faculty of Engineering and Architecture of Gazi University, vol. 35:3, pp: 1499-1508.

Esenköy Municipality (2021). Azize Paraskevi Church archive.

Eşmeli, İ. (2014). "The Church And Metaphors For 'Church' in Christian History", Turkish Studies, vol. 9(5), pp. 953-966.

Google Earth (2021). Aerial photography of Esenköy.

Güngör Açıkgöz, Ş. and Ahunbay, Z. (2008). "Conservation Proposals for the 19th Century Kayseri Churches", itüjournal/a Architecture, Planning, Design, vol. 7(2), pp. 26-37.

Olğun, T. N. and Yörür, N. (2020). "Rural Settlement Properties And Conservation Problems Of Nohutalan Neighborhood (Village) In Izmir, Urla", International Social Sciences Studies Journal, vol. 6(73), pp:4865-4886.

Tapur, T. (2009). "A Historical Settlement in Konya: Sille", Turkish Geoghraphy Journal, vol. 53, pp: 15-30.

URL 1 https://tr.wikipedia.org/wiki/Aziz_Vukolos_Kilisesi, date of access: 20.10.2021.

URL 2 https://www.izmir.bel.tr/tr/Projeler/ayavukla-kilisesikent-yasamina-katildi/1577/4, date of access: 11.10.2021.

URL

https://www.esenkoy.bel.tr/content/159/Esenk\%C3\%B6y+T arihi, date of access: 11.10.2021.

URL

https://r.wikipedia.org/wiki/Yalova_(il)\#/media/Dosya:Yalo va_districts.png, date of access: 20.10.2021. 